\title{
uma outra língua: o dizer infantil
}

\author{
carla patrícia da silva ${ }^{1}$ \\ universidade federal de alagoas, brasil \\ walter matias lima ${ }^{2}$ \\ universidade federal de alagoas, brasil
}

resumo

Este trabalho resgata um "dizer infantil", apresentado na última seção da pesquisa de mestrado, realizada entre 2014 e 2016 no Programa de Pós-Graduação em Educação da Universidade Federal de Alagoas (PPGE/UFAL), cujo tema traz "OS ENIGMAS DE INFÂNCIA E EXPERIÊNCIAS EM UMA ESCOLA PÚBLICA DA CIDADE DE MACEIÓ/AL: o que revelam?". Assim, esta pesquisa é um desejo inaugural para pensar a infância no estado de Alagoas. Buscamos neste estudo conhecer o cotidiano de crianças para problematizar quais os enigmas que permeiam as temáticas infância e experiência. Para esta pesquisa, dialogamos com a criança de Nietzsche, a partir do personagem Zaratustra presente na visão "Das três Metamorfoses". Com Kohan $(2007,2011)$, fazemos uma leitura infantil da infância, em um tempo sem determinação; o tempo aión da criança de Heráclito. Larrosa $(2009,2013)$ nos traz uma outra compreensão da experiência na medida em que ela, assim como a criança de Nietzsche e a infância em Kohan $(2007,2011)$ vem para interromper com um conforto linguístico que busca ser coerente e verdadeiro. $\mathrm{O}$ tema deste colóquio Mundos que se tecem entre "nosotros": o ato de educar em uma língua ainda por ser escrita, nos modifica, a medida que nos força a abandonar, ainda que momentaneamente, a língua adulta da filosofia e arriscar-se a escrever e ouvir em uma língua infantil. Nesta perspectiva, este trabalho traz um dos registros da pesquisa de mestrado. Nele, há um "dizer infantil" que desenha uma escola pública desde as suas próprias experiências, cuja língua não é possível de ser decifrada. E nem poderia.

palavras-chave: infância; dizer infantil; experiências.

\section{una lengua otra: el decir infantil}

resumen

Este trabajo rescata un "decir infantil" y fue presentado en la última sección de la investigación de maestría, realizada entre 2014 y 2016 en el Programa de Posgrado en Educación en la Universidad Federal de Alagoas (PPGE/UFAL), cuyo tema trae "Los enigmas de la infancia y experiencias en una escuela pública de la ciudad de Maceió/AL: ¿qué revelan?". Por lo tanto, esta investigación es un deseo inaugural de pensar la niñez en el estado brasileño de Alagoas. Buscamos en este estudio conocer la vida cotidiana de los niños para problematizar qué enigmas permean el tema de la niñez y la experiencia. Para esta investigación, establecemos un diálogo con el niño según Nietzsche, a partir del personaje Zaratustra en la visión "Las tres metamorfosis". Con Kohan (2007, 2011), se hace una lectura infantil de la niñez, en un tiempo sin determinación; el "tiempo aión" del niño según Heráclito. Larrosa $(2009,2013)$ nos trae otra comprensión de la experiencia a la vez que, como el niño de Nietzsche y la niñez en Kohan $(2007,2011)$ viene a interrumpir

\footnotetext{
${ }^{1}$ E-mail: carlaphilos@hotmail.com

2 E-mail: waltermatias@gmail.com
} 
una comodidad lingüística que busca ser coherente y verdadera. El tema de este simposio Mundos que se tecem entre "nosotros": o ato de educar em uma lingua ainda por ser escrita, nos cambia, a medida que nos obliga a renunciar (aunque momentáneamente) a la lengua adulta de la filosofía y nos lanza al riesgo de escribir y escuchar en un lenguaje infantil. En esta perspectiva, este trabajo aporta uno de los registros de dicha investigación. En él, hay un "decir infantil" que dibuja una escuela pública desde sus propias experiencias y cuyo idioma no puede ser descifrado. Tampoco podría.

palabras clave: la infancia; lenguaje de los niños; experiencia.

\section{another language: a childish telling}

abstract

This work rescues a " childish telling" presented in the last section of the master's research, conducted between 2014 and 2016 in the Graduate Program in Education of the Universidade Federal de Alagoas (PPGE/UFAL), whose theme brings "OS ENIGMAS DE INFÂNCIA E EXPERIÊNCIAS EM UMA ESCOLA PÚBLICA DA CIDADE DE MACEIÓ/AL: o que revelam?" Thus, this research is an inaugural desire to think childhood in the state of Alagoas. We seek, in this research, to know the daily life of children in order to question which puzzles permeate the childhood and experience theme. For this research, we dialogue with the child of Nietzsche, from this Zarathustra character in "The three Metamorphoses" vision. With Kohan $(2007,2011)$, we make a childish reading of childhood, in a non determined time; the "aion time" of Heraclitus child. Larrosa $(2009,2013)$ brings us another understanding of experience in that it, as the child of Nietzsche and childhood in Kohan $(2007,2011)$ is used with the intention to break a linguistic comfort that seeks to be consistent and true. The theme of this symposium Mundos que se tecem entre "nosotros": o ato de educar em uma lingua ainda por ser escrita, changes us once it forces us to leave, even for a single moment, the adult language of philosophy and run the risk of writing and listening in a children's language. In this perspective, this work brings one of the master's research records. In it, there is a "childish telling" that a public school draws from its own experiences, whose language cannot be deciphered. And neither could.

keywords: childhood; childish telling; experiments. 
uma outra língua: o dizer infantil

o dizer do personagem mais enigmático de nietzsche: o que ensina?

[...] Os infantes são estrangeiros, falam outra língua, não falam a nossa língua; contudo, temos que acolhê-los. Eis a questão principal de toda educação: como acolher a esses infantes estrangeiros? Como receber a infância? Que perguntas fazer-lhes? Que língua falar-lhe? Que convite propor-lhe? Com que forças acolhe-la? Qual hospitalidade oferecer-lhe? Como não sucumbir perante a tentação de acabar com a infantilidade da infância, em nome da tolerância, da solidariedade, do diálogo, e de tantas outras palavras bem pronunciadas? Quando a infância assoma, as perguntas não são fáceis de serem respondidas (KOHAN, 2007, p. 119).

É necessário inventarmos outros dizeres para dizer a infância. O que torna claro o valor fisiológico desta grande aventura que é pensar e escrever de modo que as regras de boa conduta não sejam o fundamento para dizê-la. Se levarmos esta questão para o contexto da educação formal, lugar onde somos ensinados a aprender e não a desaprender, o que pode ocorrer? Não sabemos exatamente. Todavia, suspeitamos que muitas línguas, letras, desenhos e rabiscos podem inscrever-se na história da experiência de infância, bem como nas nossas histórias e nas histórias dos outros. Mas também, estas inscrições, quase de forma inevitável, podem ser afetadas por um pensar a infância ainda como uma fase acabada, assim que a idade prescrita por documentos legais a alcance. Deste modo, "A infância como fase abandonada foi objeto das mais diversas tentativas de silenciamento bem como dos mais diversos sonhos de emancipação, liberdade e racionalidade que foi capaz de pensar o homem moderno" (KOHAN, 2011, p. 238). Este apontamento nos permite considerar que ao invertamos outra maneira de dizer a infância, são dissipados vários ideais modernos. Especialmente o do pensamento seguro e coerente, presentes nos raciocínios lógicos, na história da filosofia, das pedagogias e das ciências.

Zaratustra (NIETZSCHE, 2014), assim como os infates que Kohan (2007) aponta no início deste texto, também é um estrangeiro. Portanto, fala outra língua. O que supõe que sua fala é dita de outro lugar. Em consequência disto, este infante não assegura uma fala coerente e, portanto, verdadeira. Deste lugar, este 
personagem apresenta para o mundo moderno, um outro modo de dizer a infância.

A aventura filosófica de Zaratustra (NIETZSCHE, 2014) apresenta-nos um relato de experiência potencialmente criativo sobre a emancipação do sujeito exemplificada nas figuras do espírito do dragão, camelo, leão - e a criança no sentido de resgatar um dizer, no qual "[...] todas as coisas bailam; vão, dão-se as mãos, riem, fogem... e retornam. Tudo morre, tudo torna a florescer; eternamente fluem as estações da existência" (NIETZSCHE, 2014, p. 285). Esta forma de dizer é afirmativa, sobretudo porque não se coloca como modelo, sistema ou doutrina a ser seguida, mas um modo de pensar que é "[...] a minha experiência com a inspiração" (NIETZSCHE, 2006, p. 116).

A inspiração da qual o filósofo nos chama a atenção é uma experiência com o dizer. Nela, é possível perceber a criação de novos sentidos para o mundo e, assim, a fala vai sendo pronunciada como um acontecimento que sempre renova, pois não preocupa-se com uma apresentação estrutural em que o que se diz se propõe a traduzir o mundo. Pelo contrário. A fala inventa o mundo. É neste sentido a invenção nietzscheana é uma experiência com o dizer porque ambas estão intimamente ligadas com o pensamento. É neste sentido que dizer infantilmente é criar experiências de pensamento, pois possibilita múltiplas maneiras de dizer. No entanto, só o dizer não é suficiente para pensar o mundo. Em Nietzsche, como se diz é fundamental, pois é nesse como que se revela a própria experiência humana com o pensamento.

A invenção nietzscheana enquanto um modo de dizer que difere de uma estrutura lógica da qual se pretende traduzir o mundo, nos possibilita regastar um dizer infantil que ousa desmontar com o tempo que limita o dizer, o pensamento. Desse modo, a invenção nietzschena é uma relação conflituosa e de risco que o filósofo mantém consigo mesmo como um sujeito criador de dizeres. Desse modo, nasce "[...] uma figura do contratempo, pelo menos a partir do ponto de vista do tempo pontual, homogêneo, infinito, quantificável e sucessivo que é o tempo dominante desde muitos séculos no Ocidente" (LARROSA, 2009, p. 102-103). 
Larrosa (2009) nos traz uma dimensão muito importante para entender os motivos pelos quais a criança em Nietzsche é a figura da indefinição para a criação de uma filosofia outra que ele procura inaugurar na história do pensamento. Com esta marca, a figura do contratempo é a invenção mesma enquanto instante e intensidade presente no ato de dizer. Desta figura nasce uma relação artística que possibilita um encontro com uma infância primitiva que independe das contaminações em que o mundo moderno foi constituído.

É neste sentido que a figura da criança que se desloca desse tempo pontual, quantificável e sucessivo é o começo absoluto de uma nova infância porque é a mais pura afirmação da liberdade de criação no pensamento. Assim, a criança é, nas palavras do próprio Zaratustra (NIETZSCHE, 2014) “Inocência é a criança, o esquecimento, o novo começar, jogo, roda que gira sobre si mesma, primeiro movimento, santa afirmação." (NIETZSCHE, 2014, p. 42). Com isso, a origem agora, não é apenas o começo que carrega a marca da primeira etapa da existência. Essa figura infantil, criada nesse dizer que carrega a marca do contratempo, é um tempo onde

\begin{abstract}
A origem tem a ver, sim, é com o novo enquanto intemporal, enquanto êxtase do tempo, enquanto instante ou eternidade, ou caso queira, enquanto instante eterno ou eternidade instantânea. E por isso é capaz de apagar tanto o caráter de passado do passado, quanto o caráter de futuro do futuro. [...] A figura da criança não remete a uma pontuação do tempo em direção ao passado, [...] A criança não é nem antiga nem moderna, não está nem antes nem depois, mas agora, absolutamente atual, porém fora da atualidade, como tirando a atualidade de seus escaninhos e separando-a de si mesma, absolutamente presente, porém fora da presença, como separando o presente de si mesmo. A criança suprime o histórico pela aliança do presente com o eterno. Seu tempo não é linear, nem evolutivo, nem genético, nem dialético, mas está cheio de clarões, de intermitências. A criança é um presente fora do presente, isto é, um presente inatual, intempestivo. (NIETZSCHE, 2014, p. 102-103)
\end{abstract}

É nesta figura do contratempo, que as experiências "Das três Metamorfoses" deixam caminhos para questionarmos: quem é Zaratustra (NIETZSCHE, 2014)? O que fala? Por que fala? Como fala? O filósofo alemão Martin Heidegger também quis saber: “Quem é o Zaratustra de Nietzsche?” que, ao que "[...] tudo indica, é fácil de responder. Pois encontramos a resposta no próprio Nietzsche" (HEIDEGGER, 2012, p. 87). 
Quem é o Zaratustra de Nietzsche? é o nome de uma das várias conferências de Martin Heidegger, realizadas na Universidade de Freiburg por volta de 1929. Nesta conferência, Heidegger (2012) diz que:

\begin{abstract}
Assim falava Zaratustra: um livro para todos e para ninguém. É extraordinário como desde o seu aparecimento, há setenta anos, este subtítulo se faz verdade. Mas precisamente no sentido inverso. Tornou-se um livro para qualquer um e, até hoje, nenhum homem realmente de pensamento mostrou-se concrescido com o pensamento fundamental deste livro e foi capaz de medir sua gênese em toda a sua amplitude. Quem é Zaratustra? Lendo atentamente o título principal da obra, ganhamos aceno: Assim falava Zaratustra. Zaratustra fala. Ele é um falador (Sprecher). De que espécie? Um orador popular ou talvez um pregador? Não. O falador Zaratustra é um "porta-voz" (HEIDEGGER, 2012, p. 87)
\end{abstract}

Segundo Heidegger (2012), Zaratustra (NIETZSCHE, 2014) já aponta, no título da obra, de quais recursos o seu personagem principal utiliza-se para trazer uma grande novidade ao mundo moderno. Este porta-voz fala, discursa, interpreta, expõe, tenta dialogar, revela seus objetivos. O Zaratustra (NIETZSCHE, 2014) é o porta-voz de um grande nascimento que tem, na figura do além-homem, a intensidade do filosofar nietzscheano que toma a figura da criança como a grande força de manifestação do seu pensamento. Assim, a figura do além-homem é a criança que vem para ensinar, interromper com o tempo linear. Para isso, a criança de Nietzsche fala, escrever outra história; inscreve-se fora da história.

Mas, para quem Zaratustra (NIETZSCHE, 2014) fala? Heidegger apresenta suas suspeitas: “[...] Mas então o que ele proclama ou profere? A favor de que ele fala? O que ele tentar ex-por, interpretar? Será Zaratustra (NIETZSCHE, 2014) um porta-voz qualquer para alguma coisa qualquer? Ou será ele $o$ porta-voz para um que, antes de tudo e insistentemente, fala e diz respeito ao homem?" (HEIDEGGER, 2012, p. 88). Estes questionamentos travam profundas batalhas intelectuais até hoje no sentido de decifrar o que Zaratustra diz. Todavia, aprendemos com o próprio Zaratustra (NIETZSCHE, 2014) que, para criar, as batalhas acadêmicas precisam ser deixadas para trás porque o espírito do camelo e do leão não pode ser mais o anunciador de um novo tempo, pois não há novidade em seu dizer. Sua língua cansada e finalista não cria, só repete.

O porta-voz de Nietszche (2014) traz uma grande novidade. Seu dizer apresenta um tempo-devir, brincante. Este modo de dizer é o caminho que cria 
para a realização de experimentos com seus próprios pensamentos. Estes experimentos são traduzidos por nós como uma teia de imagens que evidenciam o talento arrebatador deste filósofo ao criar parábolas sucessivas que nos revelam a intensidade de seus pensamentos. Portanto, neste cenário em que as parábolas ganham um tom poético-filosófico, o dizer nesta obra não diz tudo. Todavia, não diz qualquer coisa.

Contudo, é preciso ainda ressaltar que em Assim falava Zaratustra Nietzsche persegue o objetivo de jamais conferir caráter monolítico ao texto. De igual modo, Zaratustra tem o propósito de nunca coloca-se como senhor autoritário do discurso. Nem Nietzsche nem Zaratustra procura constranger seus interlocutores a seguir um itinerário preciso, obrigatório e programado. Nem o autor nem o protagonista busca, com longos raciocínios e minuciosas demonstrações, convecê-los das pertinências de suas ideias. Nesse livro, em vez de expor doutrinas ou impor preceitos, Zaratustra limita-se a partilhar ensinamentos, comungar vivências - e isso não é pouco. Jamais lançando mão da linguagem conceitual, as posições que avança tampouco se baseiam em argumentos ou razões; assentam-se em vivências. [...] (MARTON, 2014, p. 116-117).

Vivências nesta obra são a matéria-prima para compor os cenários. Zaratustra necessita das vivências com o outro para fazer experiências de pensamento. Por isso, não existem raciocínios programados antecipadamente de modo que tenham na linguagem conceitual a verdade destas vivências. Esta postura é assumida por este personagem porque tornou-se o porta-voz do espiríto livre. Após passar dez anos dentro de uma caverna, meditando sobre a vida tornou-se infante. Transmutou-se. Agora forte, desce das montanhas por amor. Portanto, Zaratustra (NIETZSCHE, 2014) ama os homens. Por isso, quer dividir esta força com eles. Todavia, quem deseja ouvir Zaratustra (NIETZSCHE, 2014)? Quase ninguém.

"Com essa proposição, tal como se diz academicamente, definimos a essência de Zaratustra" (HEIDEGGER, 2012, p. 89): “[...] é "alguém que ensina", um "mestre". Aparentemente, ele ensina duas coisas: o eterno retorno do igual e o super-homem." (HEIDEGGER, 2012, p. 89).

Esta visão foi revelada quando Zaratustra (NIETZSCHE, 2014) estava cansado das negativas que vinha recebendo acerca do que trazia seu modo de dizer. Ninguém o queria ouvir. Mas, o que continha em sua fala para que ninguém quisesse ouvir seus ensinamentos? Temos três suspeitas: 1) O além-homem é a 
figura da ruptura; de um profundo ocaso. 2) O além-homem é a figura da indefinição; do que escapa. Como confiar nesta fala? e 3) O nascimento do eterno retorno: uma afirmação incansável pela vida que sempre retorna. Todavia, não como aquilo que já foi. Mas, como aquilo que é sempre presente, inatual. Inatual justamente por não ser compatível com o presente que só se realiza no futuro.

Zaratustra (NIETZSCHE, 2014) não se torna aquilo que é - sozinho. Os animais (seus discípulos) são companheiros fundamentais no processo de conhecimento de si do mestre. Em muitas passagens da obra, são os animais que lhe provoca muitas visões e fazem o mestre mergulhar em sonhos intempestivos. O mestre sabe da importância de ouvir os outros.

Voltando aos questionamentos de Heidegger (2012) para descobrir “Quem é o Zaratustra de Nietzsche?" ficamos com a resposta infantil de Larrosa (2009, p.93): "Zaratustra é uma afirmação pura, um canto à vida, uma chamada à transfiguração, uma figura da ligeireza, da alegria e da inocência do por vir. E a criança das três metamorfoses é um de seus múltiplos emblemas". Diante desta resposta, faz-se necessário, ainda que de forma breve, buscar Zaratustra (NIETZSCHE, 2014) no último dizer de Nietzsche.

Ecce homo: como tornar-se o que se é é uma obra publicada em 1888. Um relato autobiográfico em que Nietzsche (2016) conta como nasceu o pensamento do eterno retorno que o mantinha vivo e ativo para escrever. Neste livro, o filósofo diz que Assim Falava Zaratustra é seu pensamento mais voraz. Reportando-se a ele descreve-o como "o pensamento do eterno retorno; a mais alta fórmula da afirmação que um dia pôde ser alcançada" - é de agosto de 1881. Ele está atirado sobre uma folha com a assinatura: "6.000 pés além do homem e do tempo." (NIETZSCHE, 2006, p. 110). Com esta descrição o autor revela a intensidade dos experimentos filosóficos que traz esta obra. Assim, encontramos em Machado (2002), o que torna esta obra tão profunda e especial para Nietzsche (2014). Segundo aquele autor, é nesta obra que "[...] Nietzsche encontra a sua própria linguagem para os seus próprios pensamentos" (MACHADO, 2002, p. 19), cujo objetivo é não criar arquétipos. Mas afirmar as próprias experiências de pensamento com ele mesmo e 
com o outro, de modo que a vida jamais silencie! Por isso Zaratustra (NIETZSCHE, 2014) fala!

É fundamental esclarecer que para dizer nesta língua “[...] tem de se deixar claro, primeiro, seu pressuposto fisiológico: ele é aquilo que eu chamo de grande saúde." (NIETZSCHE, 2006, p. 113). Portanto, essa nova maneira dizer é para

[...] Aqueles cuja alma tem sede de experimentar toda a extensão dos valores e desideratos e navegar por todas as costas desse "mar inferior" idealista, aqueles que querem saber, das aventuras de suas experiências mais pessoais, como é que um conquistador e descobridor do ideal sentese, e, da mesma forma, como um artista, um santo, um legislador, um sábio, um erudito, um devoto, um eremita divino do velho estilo sentemse: eles têm necessidade, antes de tudo, da grande saúde - uma saúde que a gente não apenas tem, mas adquire e tem de adquirir constantemente, porque sempre se volta a abandoná-la [...]" (NIETZSCHE, 2006, p. 113)

Portanto, em Nietzsche (2014) “[...] o ideal de um espírito que brinca de maneira ingênua - quer dizer, de maneira involuntária, e devido a uma completude e um poder transbordante - com tudo aquilo que até hoje foi considerado santo, bom, intocável, divino [...]" (NIETZSCHE, 2006, p. 114) rompe com o dizer coerente para falar suas experiências mais íntimas. Esta posição de ruptura que o filósofo deseja ocupar na história da filosofia revela a sua atitude diante do seu leitor. Portanto, ao recusar teorias e doutrinas, o filósofo afirma repetidas vezes, as suas experiências singulares. Portanto, se há um ideal a ser seguido, é necessário que seja assumida uma postura inocente e brincante em face a tudo aquilo que foi considerado fixo e acabado no tempo. É deste lugar, como enfatiza Scarlet Marton, que as vivências como material de problematização filosófica indicam que "[...] o autor e o protagonista querem ressaltar que reflexão filosófica e vivência se acham intimamente relacionadas." (MARTON, 2009, p. 117).

Esta relação que Nietzsche (NIETZSCHE, 2014) realiza entre o ato de pensar e viver apresenta a dimensão do que ele diz quando filosofa. Para aproximar pensamento e vida, determinados valores como, por exemplo, a concepção de tempo, seja reavaliado. Por isso, Zaratustra não apenas diz o tempo. Mas também canta, discursa "[...] conversa com os seus animais e troca segredos com a vida. E na maior parte das vezes o falar esconde mais que o calar; o silêncio 
revela mais do que as palavras." (MARTON, 2009, p. 119). Por tanto, quando o filósofo cria um jogo em que nem sempre o dizer diz alguma coisa, e o silêncio pode dizer aquilo que as palavras não conseguem, ele usa outras ferramentas para desmontar tudo aquilo que fora dito sobre o pensar e viver de maneira universal. Dessa perspectiva, se o filósofo faz profundas críticas aos valores do seu tempo, necessariamente é preciso assumir a condição de extemporâneo.

O dizer de Zaratustra (2014) é criativo, intensivo e indecifrável. Estes adjetivos o colocam como o anunciador de um novo tempo. $\mathrm{O}$ tempo-devir; sem determinações. A criança que brinca, canta e conversa com os animais. Assim como Nietzsche (2014), Kohan (2007) também assume esta condição a medida que coloca a infância em um tempo do eterno começo.

Em "Ainda novos ares para a infância: tempo e devir", encontramos dois tipos de temporalidade; a do tempo-devir e a do tempo-história. Este último é marcado por acontecimentos que justificam-se pelas causas e efeitos. Todavia, este “tem lugar fora da história" (KOHAN, 2007, p. 92) porque é um modelo que apresenta a história como um acontecimento já dado. Com esta marca, o tempohistória é identificado neste texto como o tempo das maiorias. Portanto, o tempo que predomina nas relações com os outros, nas relações dentro da escola. Este modelo representa o tempo chrónos que, “[...] Em grego clássico há mais de uma palavra para referir ao tempo. A mais conhecida entre nós é chronós, que designa a continuidade de um tempo sucessivo. [...] O tempo é, nessa concepção, a soma do passado, do presente e do futuro, [...]" (KOHAN, 2007, p. 86).

Por outro lado, encontramos o tempo aión “[...] que designa, já em seus usos antigos, a intensidade do tempo e da vida humana, um destino, uma temporalidade não numerável nem sucessiva, intensiva." (KOHAN, 2007, p. 86). Esta é a marca do tempo-devir, o tempo das minorias que Kohan (2007, p.92) denomina de "[...] o acontecimento mesmo, a criação, o que Nietzsche chamava de intempestivo. [...]". No tempo-devir em que é a descontinuidade quem dita seu próprio rítmo, nasce um acontecimento que interrompe a lógica do tempo chrónos. Cria-se agora o tempo aión; um novo início; “[...] Por isso, o devir é 
sempre minoritário" (KOHAN, 2007, p. 92). Nesta perspectiva, o tempo devir, por deslocar-se para fora da história contínua é nômade, viajante, se move para lá e para cá.

Neste sentido, o que diferencia estes dois tempos é a intensidade com que se apresentam; como criam experiências, possibilidades de realidade. Nesta perspectiva, o tempo chrónos e o tempo aión são pensados da seguinte maneira por Kohan (2007, p. 93), a partir das leituras de Deleuze: “[...] Enquanto os segmentos molares concentram, centralizam e totalizam, os fluxos moleculares vazam, escapam à captura, se conectam na diversidade, fogem da centralização e da totalização [...]". A partir desta língua que potencializa o nosso modo dizer neste estudo, a língua infantil da escola estudada, ecoa afirmativamente neste modo de dizer minoritário, presente em Zaratustra (NIETZSCHE, 2014) e em Kohan (2007). Portanto, atentos para outros modos de existência na escola, questionamos: 1) o que ocorre quando o dizer infantil se coloca como avaliador do cotidiano escolar?3 2) o que esse dizer vem anunciar? e 3), por último, o que esse dizer possibilita pensar os espaços organizados para infância na escola?

\section{a infância na escola: a fala mais afirmativa para dizer este lugar}

É na infância que cada ser humano se apropria da linguagem e faz do sistema de sinais adquirido um discurso com sentido, isto é, se constitui em sujeito da linguagem ao dizer "eu". A infância, carente de linguagem, é também sua condição de emergência. Mas também o acesso à infância apenas pode acontecer pela linguagem. [...]" (KOHAN, 2011, p. 241)

A fala infantil, por vezes, é anulada quando as experiências pedagógicas administram a vida de crianças no espaço escolar. O discurso e o cotidiano pedagógico sintetizam a tessitura das experiências que habitam o contexto da escola estudada. Neste espaço, onde o dizer infantil é anulado por um modelo que

\footnotetext{
${ }^{3}$ Quando colocamos o "dizer infantil" como avaliador da escola, estamos enunciando que, ao dizer algo, conferimos determinados valores. E isto também se revela naquilo que as crianças dizem sobre os espaços ocupados por elas no cotidiano da escola estudada. Todavia, "o dizer infantil" confere valores diferentes dos que partem da desigualdade de fala. Assim, o espírito infantil, a saber, as crianças que participam desta pesquisa, avaliam este lugar em uma língua outra. Neste sentido, o "dizer infantil", ao avaliar a escola, ensina-nos o que pode ser o escolar, ao ampliar o sentido atribuído à infância e à experiência, alertando, sem acusar, que as intenções pedagógicas não conseguiram capturá-las completamente.
} 
prima pela lógica da infância marcada por um tempo fixo e, por conseguinte, de experiências que se alinham à este, nos levou a apreciar uma experiência de linguagem que não estava em nossos planos de pesquisa quando traçamos quais perguntas seriam feitas às crianças.

Após um longo período de observação, chegou o momento de ouvir as falas das crianças acerca da escola. Esperávamos trazer uma série de transcrições com as respostas delas para compôr os registros da pesquisa. Todavia, os planos foram alterados diante do que traziam, bem como a maneira que apresentaram a escola.

Os maiores questionamentos de nossa pesquisa foram: como receber as crianças? Como chegar até elas? Como dialogar com elas? O que fazer para conseguir que aceitem falar conosco? Como fazer para que respondam às nossas perguntas? Estes questionamentos nos levaram a pensar que “[...] Seria bastante fácil se colocar no lugar de decifrador do enigma" (KOHAN, 2007, p. 126). A saber, de revelar a essência de suas falas. Todavia, afirmamos uma postura onde não eram as nossas intenções que estão em jogo. Com esta compreensão, ao invés “[...] de tentar falar por uma criança estrangeira ou dar conta de suas supostas intenções, [...]" (KOHAN, 2007, p. 126) optamos por pensar um novo início, um outro ponto de partida, afirmativo, inocente. [...]" (KOHAN, 2007, p. 126). Desse modo, esta mudança de lugar nos levarou a demorar nas observações ${ }^{4}$.

Isto é bastante elucidado do sentimento que nos tomava: o medo de aproximar-se das crianças porque sabíamos que elas poderiam nos desconcertar. Isso porque “[...] Quando a infância assoma, as perguntas não são fáceis de serem respondidas" (KOHAN, 2007, p. 119). Nisto, também, há a marca da filosofia que vimos afimando neste estudo. A justificativa desta escolha toma concretude, mesmo que ela ainda nos escape. Assim, afirmamos esta filosofia “[...] Porque a resposta filosófica não acalma uma inquietude, mas a potencializa. Quem sabe, por isso, valha apena responder em filosofia. Porque poderemos seguir perguntando e respondendo, cada vez mais radicalmente" (KOHAN, 2011, p. 185).

\footnotetext{
${ }^{4}$ Ainda que durante as observações, tenhamos criado uma relação quase de intimidade com as crianças.
} 
O sentimento do medo é revelador da "[...] Nossa infantilidade [, que] esconde uma abertura, um começo, que se projeta no porvir; é outra infantilidade, a de quem questiona sua própria prática; no começo, a pergunta e suas tentativas de resposta instauram em nossa compreensão um início sobre o que significa ensinar, [...]" (KOHAN, 2011, p. 183). Para nós, pensar o que pensa a infância; aprender com ela e, sobretudo, um vir-a-ser que propocie pensar a infância na escola.

Kohan (2011) questiona, em seu livro Infância. Entre Educação e Filosofia, "o que significa ensinar?". Esta pergunta nos sugere um modo de pensar intempestivo quando nos perguntamos "o que pensa quando a infância pensa?". Então entendemos que

[...] estamos ante uma pergunta complexa, aberta, polêmica, com uma longa história de enunciações e pretensas soluções. Não a trataremos compreenssivamente. Não a esgotaremos. Recriaremos-la. Mostraremos um território onde essa pergunta poderá ser pensada outra vez, abordada a partir de perspectiva infantilmente filosófica. Não só porque tratar essa pergunta extensivamente levaria a outro tipo de trabalho, mas também porque, numa perspectiva infantil, problemas como esse não encontram soluções definitivas, não aceitam soluções. (KOHAN, 2011, p. 183)

Não sabíamos o que pensa a infância até pergunta-la. Ao perguntá-la, a infância nos confude. Todavia, respeitamos seu modo de dizer porque “[...] Suspeitamos que qualquer resposta não conseguirá abarcar a radicalidade do problema. Nisto também há uma marca da infantilidade de um perguntar e um responder. [...]" (KOHAN, 2011, p. 185). É com esta clareza que apresentamos o dizer infantil, acerca da leitura que fazem da escola. A dimensão das suas respostas não é definitiva, tampouco elas aceitam interpretações, no sentido de capturar conceitualmente o que elas querem dizer. Por isso,

[...] não pretendemos mostrar, nem justificar, um certo conhecimento que mostre nosso domínio sobre a questão. Temos que admitir que não a dominamos. E que não queremos dominá-la. Apenas queremos pensá-la. Apresentaremos, para isso, um mapa, uma geografia, onde essa pergunta se possa pensar mais amplamente do que usualmente se faz no campo da Filosofia da Educação. (KOHAN, 2011, p. 183-184)

A ideia inicial era criar condições para que as entrevistas acontecessem de modo que não fossem confudidas com as atividades pedagógicas que eu havia 
observado. Pensamos que, ao deslocar as crianças das experiências pedagógicas observadas, elas sentiriam confiança em nós 5 .

No primeiro contanto, pedimos para que as crianças tirassem seus tênis e chinelos e sentassem em um pedaço de $\mathrm{TNT}^{6}$ e entregamos interrogações feitas com folhas E.V.A. Com isto, queríamos sinalizar que iríamos conversar com elas. A imagem abaixo representa um pouco deste primeiro momento com as crianças.
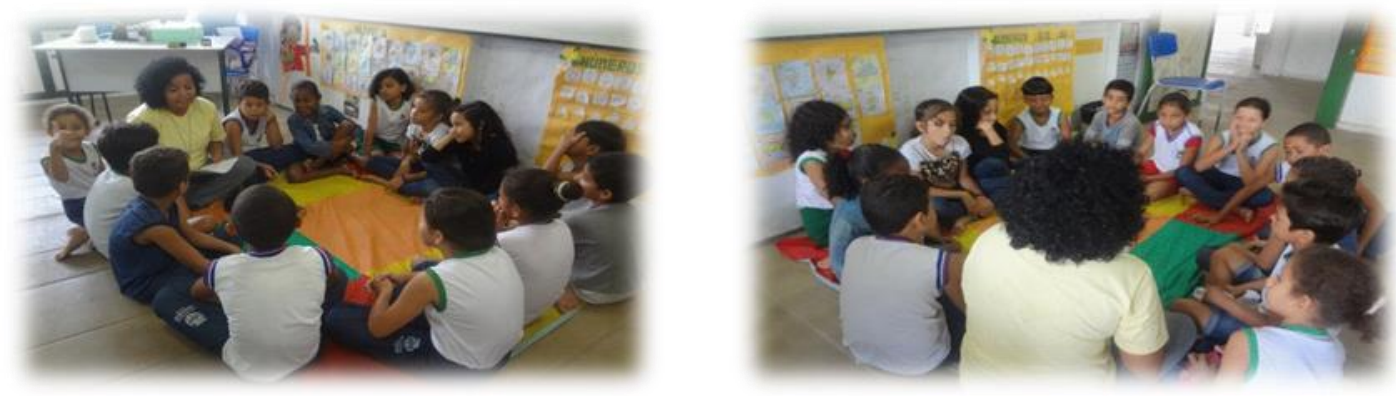

Fonte: arquivo dxs autorxs

As imagens mostram o momento em que as lembrávamos da razão para estarmos ali. Queríamos conhecê-las, a partir do que vivenciavam na escola. Por isso, naquele momento, quisemos fazer-lhes algumas perguntas ${ }^{7}$.

No decorrer, as crianças começaram a apresentar desinteresse nas perguntas. Não respondiam as perguntas que versavam sobre: 1) O que gostam de fazer na escola? 2) Quais são os lugares mais preferidos por vocês? 3) Qual atividade mais gostam de fazer? 4) O que vocês não gostam de fazer na escola? Com as respostas, queríamos saber o motivo, as justificativas.

Pode parecer que ao fazer estas perguntas, queríamos identificar, localizar as crianças. As crianças pareciam envergonhadas para responder às nossas perguntas. Olhavam umas para as outras e começavam a sorrir. Eu parava e pensava: e agora? O que vou fazer para saber o que se passa com estas crianças? Então pensei que se as próprias crianças perguntassem umas para as outras, a

\footnotetext{
${ }^{5}$ Para a realização das conversas com as crianças, era possível que a professora disponibilizasse o momento de alguma aula, para que as conversas acontecessem. Desse modo, deixava a professora à vontade para dizer o dia e o horário mais confortável para ela. Com a afirmativa da professora, começávamos as converas com as crianças.

${ }^{6}$ Um tipo de tecido que não é tecido. Este tecido consegui com a professora da turma. Posteriormente, levei um tecido T.N.T. para esses momentos.

${ }^{7}$ Neste momento, eu ainda não havia entregado os pontos de interrogação.
} 
resposta viesse. Mas isto não aconteceu. As crianças continuavam envergonhadas e ao mesmo tempo muito agitadas.

Em consequência disto, começavam a jogar as interrogações umas nas outras. Algumas crianças ainda tentaram responder:

- O recreio. Porque lá eu corro!

- A sala. Porque eu faço dever!

Então eu perguntei: quem aqui gosta de desenhar? Algumas responderam levantando o braço gritando:

\section{- EEEuนuи!}

Queríamos que, ao perguntar, as crianças respondessem. Todavia, não foi possível. É claro que não! Diante da autonomia das crianças, a maneira como as perguntas foram feitas, mudaram. E, consequentemente, as respostas também. Diante disto, parei um pouco. Deixei que as agitações continuassem, ainda que a professora quisesse ajudar-me ao tentar controlar a agitação das crianças.

Pensando no início em que pensava sobre o que perguntar às crianças, mas sobretudo, como perguntar, lembrei que eu não queria identificá-las, nomeálas. Sabia que eram criativas. E foi por esta via que eu pensei ser possível aproximar-me delas. Foi então que sugeri os desenhos.
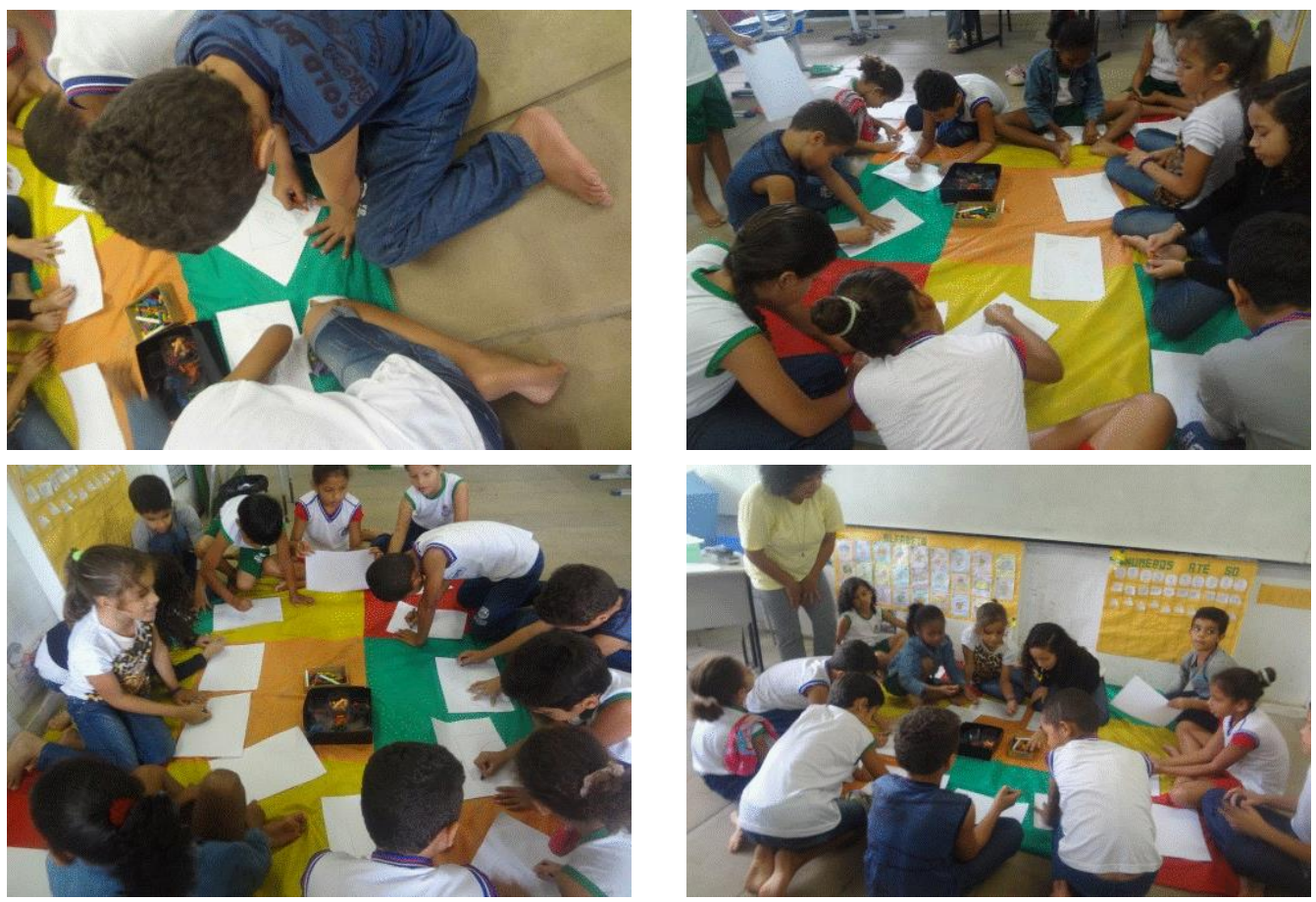

Fonte: arquivo dxs autorxs 
No momento em que faziam os desenhos, alguns implicavam com o outro porque estava usando muitos lápis, deixando os outros sem material para desenhar. No meio desta aparente bagunça, algumas falam:

- Vou desenhar uma escola bem bonita!

Ou ainda:

- Eita! Vou desenhar a minha sala!

- Eu vou desenhar aquele pedaço onde a gente fica em cima da grade!

- Vou desenhar a caixa d'água da escola! Uma escada bem grande!

Durante este momento, algumas crianças se levantam e resolvem desenhar nas cadeiras onde habitualmente sentam quando chegam à sala de aula. Outras, não querem sair do TNT, permanecendo lá até o final do desenho como pode ser visto abaixo.
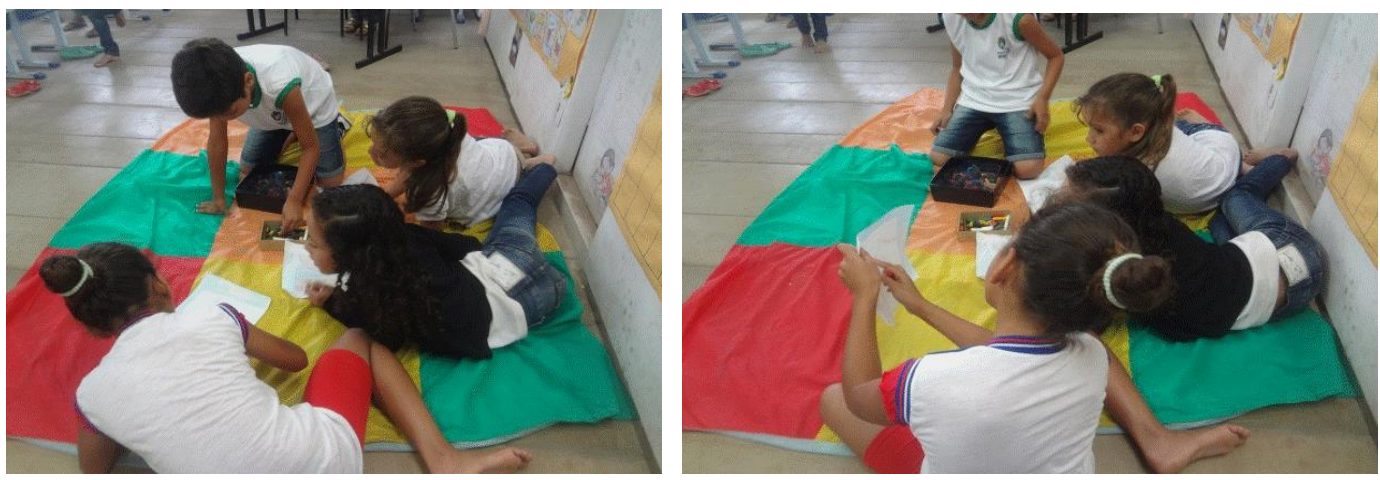

Fonte: arquivo dxs autorxs

Ao término do desenho, todos me entregam seus dizeres, calçam os tênis e chinelos e voltam para os assentos de costumes.

No outro dia, três crianças vieram perguntar-me se faríamos novamente aquela "tarefa". Com esta pergunta, respondi com uma outra. Perguntei se haviam gostado da "tarefa". Responderam que sim. Com isto, respondi que naquele dia não. Mas teríamos outros momentos juntos.

Pensei que seria interessante continuar essas entrevistas em outro espaço. Escolhi o da sala dos professores. Lugar ainda não ocupado pelas crianças, visto que, era "a sala dos professores". Diante das demarcações que a escola faz, ao destinar os espaços para cada função ou pessoa, a ideia era habitá-los em um lugar incomum ao seu cotidiano. 
Era latente a surpresa das crianças em saber que iriam para a sala dos professores. Muitos momentos, infelizmente, não puderam ser registrados porque era eu quem "organizava" as crianças e o local para recebê-las. Desse modo, nem as imagens conseguem sintentizar a surpresa delas em adentrar em um lugar onde nunca estiveram. Todavia, as imagens abaixo representam um pouco de um dos nossos momentos neste espaço.
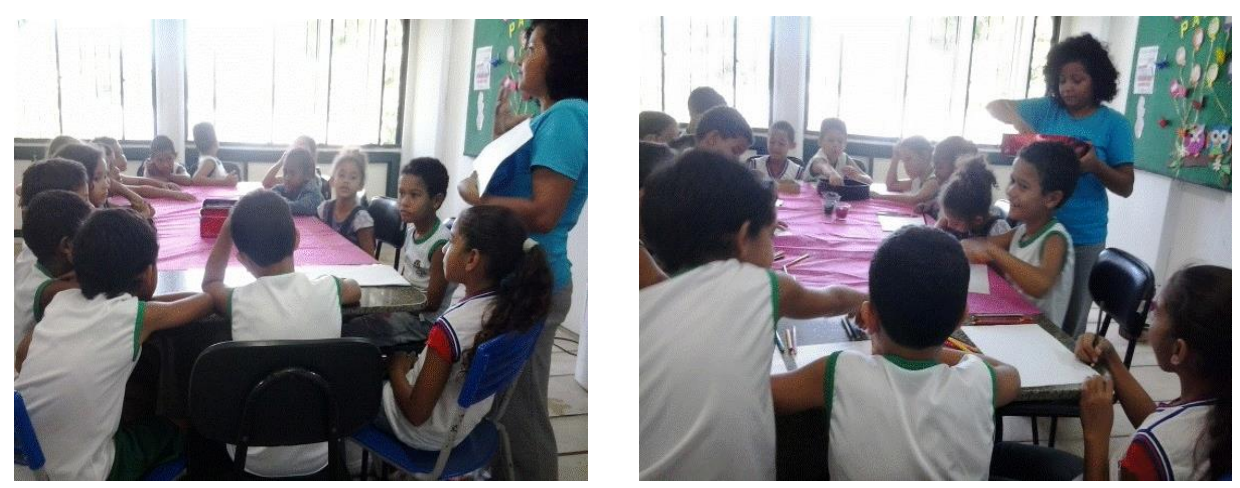

Fonte: arquivo dxs autorxs

A primeira imagem da esquerda para a direita, mostra que, enquanto eu falo sobre o que iríamos fazer naquele momento, uma das crianças que está na ponta da mesa, olha para fora da janela. Esta janela é igual à da sala de aula dela. Todavia, ainda não havia visto o que tinha fora daquela janela. Na imagem à direta, ela volta para o que estávamos fazendo.

Continuamos com as mesmas temáticas: o dizer das crianças sobre a escola. Seu dizer é uma leitura, uma intepretação, seus afetos sobre este lugar organizado para acolhe-las.

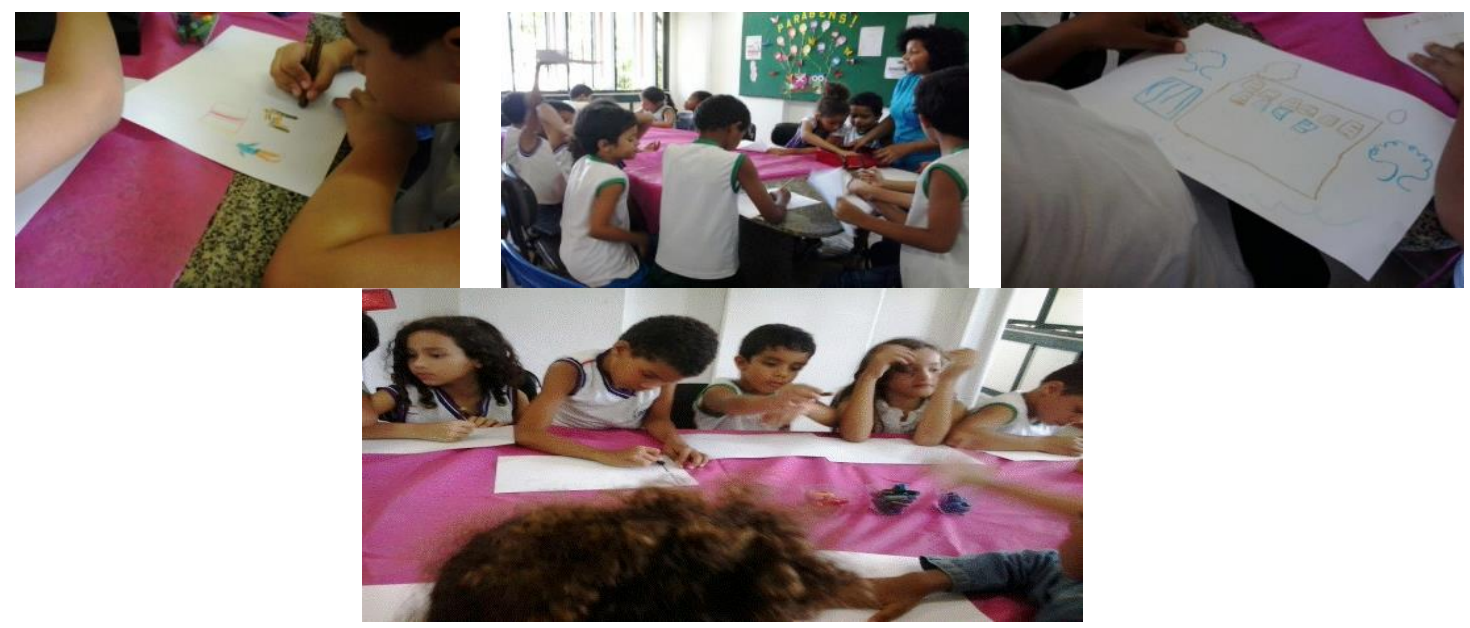

Fonte: arquivo dxs autorxs 
Estas imagens mostram o trabalho infantil para dizer a escola. As crianças pensavam no que desenhar, como desenhar. Escolhiam as cores, o tipo de lápis. Avaliavam o desenho dos colegas. Neste processo, a língua se confunde com a língua dos outros para dizer a escola, quis esclarecer o sentido para o que estava no papel. Desse modo, não houve repetição ou cópia do desenho do outro. Mas a criação mesmo!

Neste processo, durante e após a criação dos desenhos, as crianças vinham mostrar-me e explicar o que sua leitura queria dizer.

- Tia está vendo isso aqui? É lá na entrada da escola. Olha! Aqui é onde os nossos pais e colegas ficam. Aí, a gente passa por estas grades. Vem, vem e vem e chega na sala!

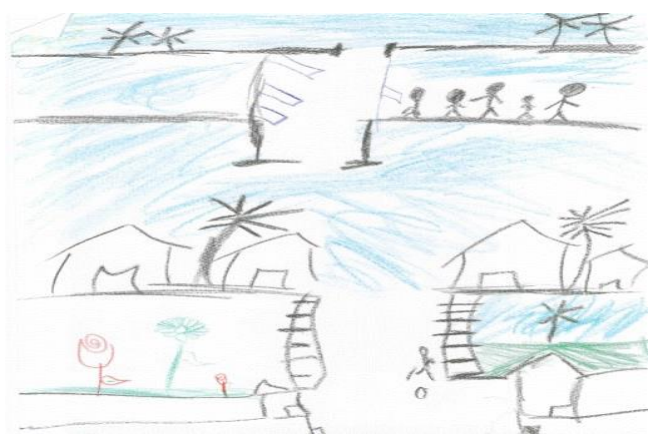

Fonte: arquivo dxs autorxs

Esta criança desenha o percurso e o que há nele até chegar à sala de aula. Lugar que nos parece ser o mais privilegiado da escola. Lugar onde as coisas são feitas.

Há uma outra língua muito curiosa. Esta mostra um pouco do espaço do intervalo, lido por outra criança.

Fonte: arquivo dxs autorxs 
- Tia, essa aqui é a caixa d'água. A sinhora sabe, né?! Que fica ali no meio do recreio. Olha essa escada grande! Sempre fico imaginando como é subir nela!

Este dizer é revelador do que os elementos que existem neste espaço, provocam no imaginário desta criança. Mais uma vez, o tempo e o espaço controlados pelo discurso pedagógico, se dissipam frente a imaginação infantil.

O dizer infantil também lembra os lugares não frequentados por eles. Estes lugares podem ser lidos abaixo.

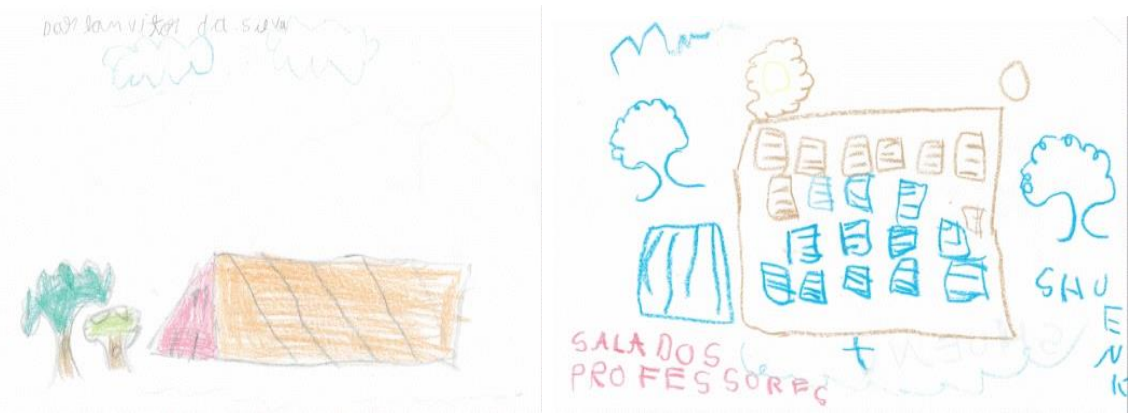

Fonte: arquivo dxs autorxs

O primeiro dizer, da esquerda para a direita, mostra a quadra de esportes, desativada há quase uma década por falta de recursos públicos. Era neste lugar onde as crinças faziam educação física e onde ocorriam festas e reuniões de pais. Curiosamente uma criança desenha a sala dos professores. Lugar em que parte dos desenhos foram criados. Houve uma tentativa de mostrar a organização da sala e as árvores que é possível ver da janela.

A sala de aula, lugar em que as crianças ficam a maior parte do tempo, é frequente nos desenhos. Podemos perceber isto, quando as crianças dizem como a sala é organizada. O modo como os assentos habitualmente estão dispostos é representado nos desenhos abaixo. O lugar de onde a professora fala também é observada. As crianças revelam também, a maneira como toda a escola é distribuída.
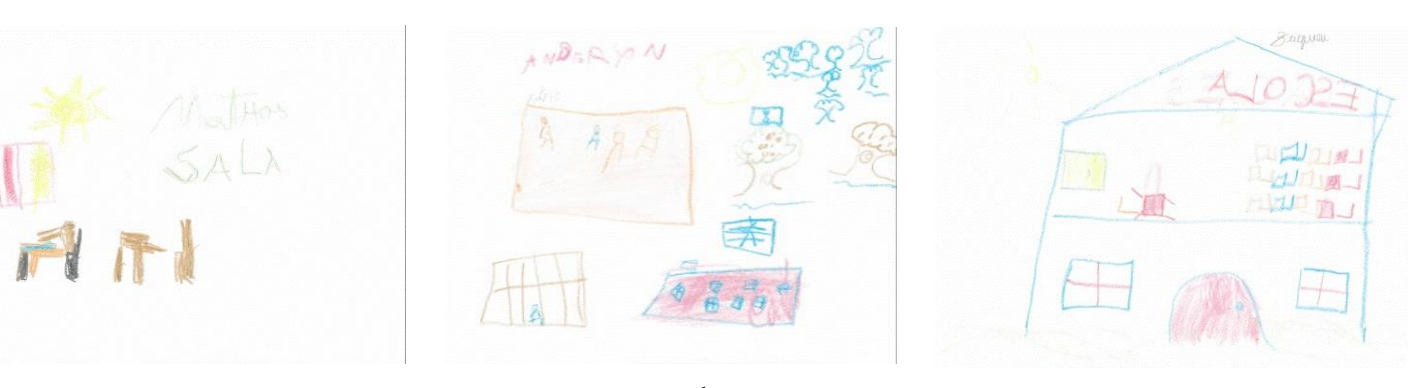

Fonte: arquivo dxs autorxs 
A infância revela a maneira como a escola é organizada e, ao mesmo tempo, as intenções. A aprendizagem, resultado do ensinar pedagógico, é "trabalhada" na sala de aula. Aqui, a aprendizagem é reforçada na leitura que as crianças fizeram deste espaço. O lugar mais escrito pelas crianças é o pátio. Este é o lugar em que as crianças mais fazem aparecer, ganham destaque e um certo tom de alegria. Elementos como um coração, o sol e as brincadeiras, são representativos deste sentimento.
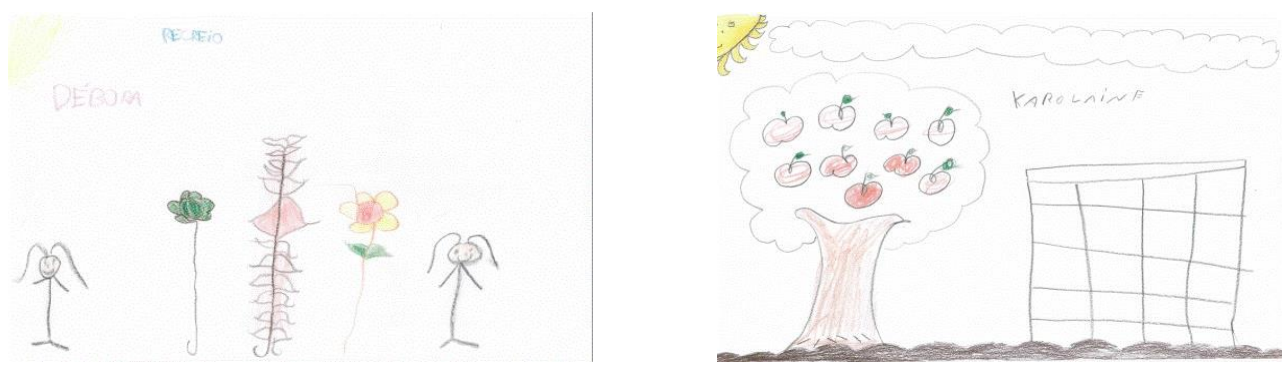

Fonte: arquivo dxs autorxs
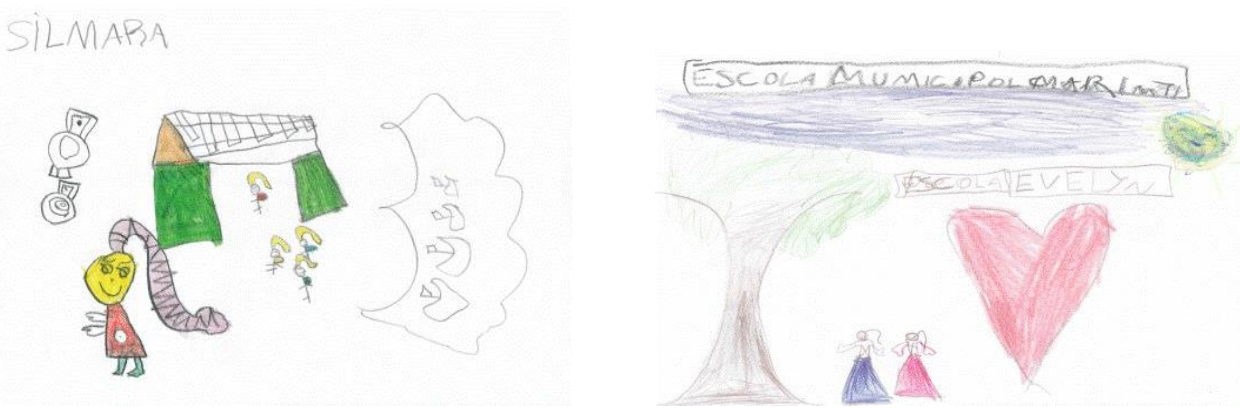

Fonte: arquivo dxs autorxs

O pátio é o lugar mais esperado pelas crianças. Os desenhos mostram a razão deste sentimento. Este lugar, apesar de ter uma série de problemas estruturais, pulsa vida. Cheio de árvores frondosas, chão de terra batida e muitas crianças correndo para lá e para cá, brincando com o tempo, vivifica a escola. Os gritos, as correrias, o sol sempre alto e quente de quase todos os dias, o "fazer o que quiser" e a ausência do dever, legitimam este ser o lugar que mais afeta as crianças.

Neste momento, é necessário reportarmos aos escritos de Kohan (2011). Ao pensar com Deleuze o acontecimento da infância, o autor assevera a vitalidade 
da infância como a que tentamos mostrar na relação que as crianças estabelecem com o pátio. O intervalo revela que o tempo e espaços do pátio propiciam que as crianças recuperem a infância como quem busca "[...] encontros e resiste aos agenciamentos individualizadores e totalizadores, mas que aposta na sigularidade do acontecimento. [...]" (KOHAN, 2011, p. 253). Com isso, será o pátio que recupera a infância? Ou será que as crianças recuperam o pátio porque afirmam a infância? As duas questões são bem possíveis. Retornemos a Kohan (2011, p. 252):

\begin{abstract}
A infância é a positividade de um devir múltiplo, de uma produtividade sem mediação, a afirmação do ainda não previsto, não nomeado, não existente; a asseveração de que não há nenhum caminho preterminado que uma criança (ou um adulto) deva seguir, que não há nenhuma coisa que ela (ou ele) deva se tornar; a infância é "apenas" um exercício imanente de forças.
\end{abstract}

Há muitas infâncias que rondam o pátio. Muitas delas, conseguem exercitar suas forças porque conseguem produzir, criar, dizer de um modo em que não há uma previsibilidade ou mesmo o produto deste exercício de ser infantil. A ausência de determinação ou suspensão da ordem que administra os outros espaços da escola tem no pátio um lugar onde a infância pode ser demasiadamente infantil. Desse modo, é possível notar a afirmação de uma “[...] diferença livre de pressupostos. Vida experimentada; expressão de vida; vida em movimento; vida com experiências." (KOHAN, 2011, p. 253). Por este modo de experimentar viver, o dizer infantil não condena a escola. Mas a absorve.
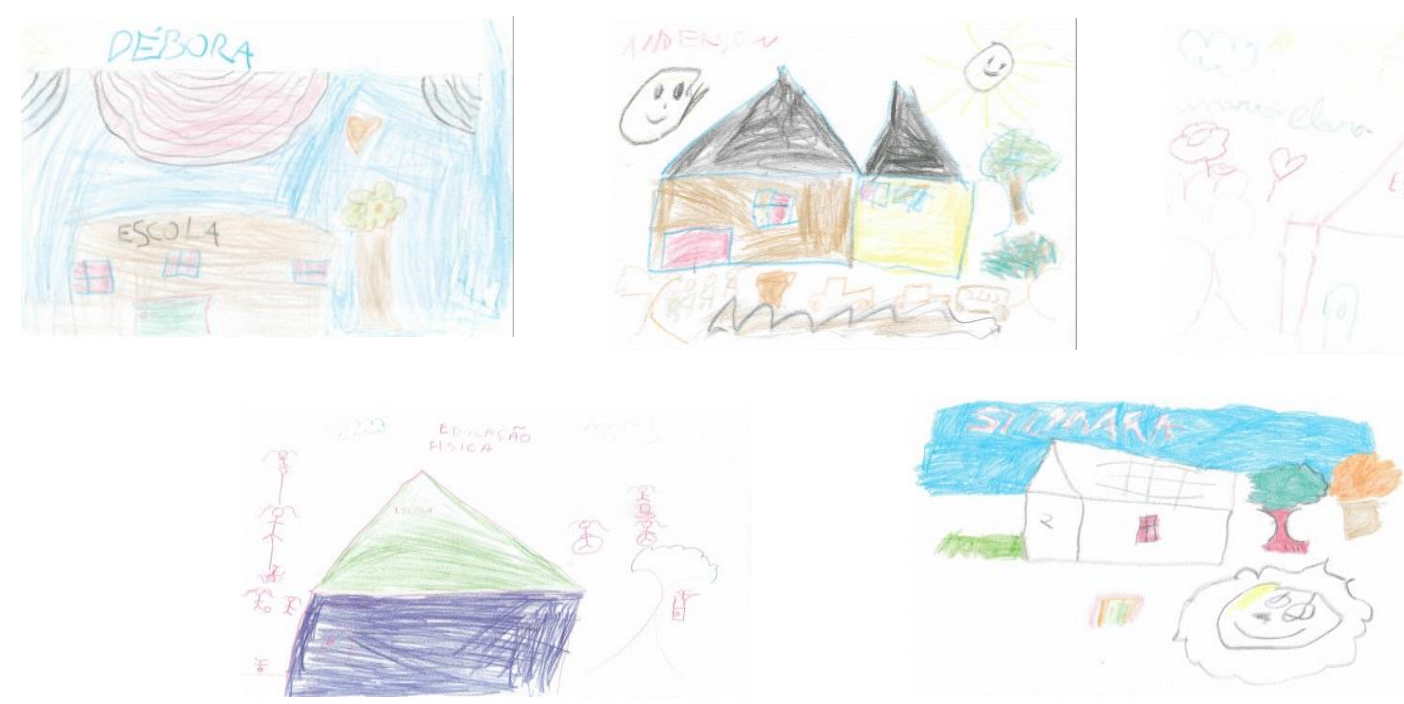

Fonte: arquivo dxs autorxs 
O dizer infantil afirma com alegria este lugar. Ainda que, cheio de boas intenções, a escola, por vezes, o condene; censure a infância. Mas voltemos às falas das crianças que, ao nosso olhar, parecem mais profundas.

O dizer infantil sugere que pensar exige coragem e, sobretudo, criatividade. Neste sentido, esta língua não quer dizer que tudo seja encarado como belo e afirmativo. Este dizer vem para ensinar-nos que é porque criamos que pensamos. A falta de criatividade não revela enigmas, não é afetada, muito menos alegre em meio a dizeres fixos e acusadores que prescrevem a maneira como a infância deve ser, viver e dizer. A falta de criatividade, sobretudo, não gera educação. A língua adulta da filosofia, por exemplo, sabe muito bem o que é viver sem criar. Sabe muito bem como não ensinar. Neste sentido, a figura da criança de Heráclito e de Nietzsche é inspiradora e complexa demais para a filosofia e para a escola, pela superioridade com que diz os seus saberes.

Ainda que o dizer infantil apresentado neste estudo pareça dizer o que qualquer criança diria sobre a escola, contribui para abrir sentidos à uma nova língua, mesmo que sempre presente na escola. Esse dizer a escola, pensado por nós como um início, "[...] exige, então abrir nossa sensibilidade para pensar com a infância, de iguais para iguais, despojando-nos do que nossos saberes já capturaram, do que já conhecem, dos pontos de chegada que já pensaram a educação da infância na língua adulta da filosofia. [...]” (KOHAN, 2007, p. 133).

Decifrar os enigmas do dizer infantil é desautorizar um dizer que é autoexplicativo. O que interessa para nós é a maneira de dizer dessa infância que não faz julgamentos. Portanto, esta infância não condena. "Apenas" dá sinais, deixa o que pensar sobre a maneira como é interpretada pela escola e, sobretudo, a criatividade com que diz suas experiências em um lugar onde falta espaço, mas sobra deveres para elas. Assim, sem dizer na língua esperada, sem dizer tudo, a infância ensina. Ao ensinar, nos revela quatro visões que nos forçam a pensar sem domínio de um dizer. Mas, sobretudo, pensar. São elas: 1) Repensar o sentido que damos quando ensinamos. Assim, ao ensinar, não pensamos sobre o que ensinamos. Por não pensar, não ensinsamos. 2) Estar aberto para os encontros. 
Sem abertura para o outro, para pensar junto é impossível a educação. Por não pensar junto, a educação cria hierarquias; afirma a desigualdade. 3) Errar sem culpa. O peso da culpa, gerado pelo cumprimento dos deveres, proíbe de errar. Neste sentido, o acerto ou a verdade é o princípio para pensar bem em educação. Os questionamentos, portanto, não existem quando dizer em educação pauta-se nas certezas. Essa lógica, por não abre-se para a infância e a vivência com o outro, cria sujeitos ressentidos e cansados da vida. 4) Desejar a infância para dizer em outra língua.

Desse modo,

[...] A infância fala uma língua que não se escuta. A infância pronuncia uma palava que não se entende. A infância pensa um pensamento que não se pensa. Dar espaço a essa língua, aprender essa palavra, antender esse pensamento pode ser uma oportunidade não apenas de dar um espaço digno, primordial e apaixonado a essa palavra infantil, mas também de educar a nós mesmos, a oportunidade de deixar de situar sempre os ouros em outra terra, no des-terro, no estrangeiro, e poder alguma vez sair, pelo menos um pouquinho, de nossa terra pátria, de nosso cômodo lugar. Essa parece ser uma das forças da infância: a de uma nova língua, de um novo, outro, lugar para ser e para pensar, para nós e para os outros. (KOHAN, 2007, p. 131)

A infância, língua que não se escuta, é ouvida neste estudo. Muitos não a entenderão; outros a considerarão óbvias demais. É muito confortável rejeitar o que não se entende. Há muito disso em educação. Do mesmo modo é cômodo procurar explicar esta língua a partir de leis universais e necessárias quando se trata de dizer a infância, ao querer dar conta de sua realidade. Neste sentido, o estrangeiro e o desconhecido, ou mesmo aquele que pensamos conhecer, cria em nós a necessidade de identificação. Todavia, é chegada a hora do grande começo. De sair do nosso cômodo lugar para pensar. Este momento é bastante significativo porque não precisamos de despedidas ou mesmo justificativas. Os começos sempre causam esse tipo de rebeldia. Como a que causou a morte do ateniense Sócrates que, segundo Kohan (2007, p. 122), “[...] foi, na sua defesa, uma criança nietzschena: ingênuo, brincalhão, afirmativo. [...]”. Sim! Somos ingênuos por desejar que infância e experiências não sejam medidas com fita métrica, calendários e relógios de pulso. Mas pela intensidade do seu modo de dizer que nos convida a criar enquanto pensamos; viver a escrita; viver. 
De uma forma narrativa que não pensa a partir de conceitos, mas imagens, a criança, em Nietzsche (2014), problematiza a vida pelas experiências sempre em movimento. Em consequência disso, o tempo da infância, em Nietzsche (2014), afirma as experiências com alegria, porque deseja inventar "[...] novos cantos". Mas, para isto, "é preciso uma lira nova." (NIETZSCHE, 2014, p. 288), a saber, uma nova leitura sobre a criança e a infância. Desse modo, há a "[...] possibilidade de recriar o que parece cansado, gasto, velho, na própria filosofia." (KOHAN, 2011, p. 118), bem como na pedagogia.

A infância, portanto, aparece neste estudo, em uma nova língua para inventar outras formas de vivenciar e pensar. Nesta vertente, pensar o dizer infantil é considerar as experiências que estão fora dos planos pedagógicos. É neste sentido que as personalidades de Nietzsche (2014) e Kohan (2007) inauguram pensamentos de infância que nos ajudam a problematizar o que ocorre quando a minoridade do pensamento foge à lógica dos planos educacionais.

Nos parece claro que o que a infância nesta escola diz ultrapassa os limites desta escrita. Por isso, a infância ter relação com a educação. Por isso, a educação escolar necessitar da infância, experimentar o devir-infância. Dizer em outra língua.

\section{referências}

HEIDEGGER, Martin. ¿Quién es el Zaratustra de Nietzsche? Traducción de Eustaquio Barjau. In: Conferencias y artículos. Barcelona: Ediciones del Serbal, 1994. KOHAN, O. Walter. Infância, estrangeiridade e ignorância. Ensaios de filosofia e educação. Belo Horizonte: Autêntica, 2007.

Editora, 2011.

Infância. Entre educação e filosofia. 2. ed. Belo Horizonte: Autêntica MARTON, Scarlet. Nietzsche e a arte de decifrar enigmas. Treze conferências europeias. 1. ed. São Paulo: Edições Loyola, 2014. (Coleção Sendas \& Veredas)

NIETZSCHE, W. Friedrich. Assim Falava Zaratustra: um livro para todos e para ninguém. Tradução e notas simólicas nietzscheana do Mário Ferreira dos Santos. 7. ed. Petrópolis: Vozes, 2014. (Coleção Textos Filosóficos)

Ecce Homo: de como a gente se torna o que a gente é. Tradução, organização e notas de Marcelo Backes. Porto Alegre: L\&M, 2006.

LARROSA. Jorge. Pedagogia Profana: danças, piruetas e mascaradas. Tradução de Alfredo Veiga-Neto. Belo Horizonte; Autêntica Editora, 2013. 
Desejo de realidade. Experiência e alteridade na nvestigação educativa. In: BORBA, Siomara; KOHAN, Walter Omar. Filosofia, aprendizagem, experiência. Belo Horizonte: Autêntica Editora, 2008.

Nietzsche E Educação. Traduzido por Semíramis Gorini da Veiga. 3. ed. Belo Horizonte: Autêntica, 2009.

. Escritos sobre educação. Introdução, apresentação e notas de Noéli Correia de Melo Sobrinho. Rio de Janeiro: Ed. PUC-Rio: São Paulo: Loyola, 2003.

Recebido em: 20.10 .2016

Aceito em: 08.11.2016 